\section{Transplant Timing Affects Early Root System Regeneration of Sugar Maple and Northern Red Oak}

\author{
J. Roger Harris ${ }^{1}$, Jody Fanelli², and Paul Thrift ${ }^{3}$ \\ Department of Horticulture, Virginia Polytechnic Institute and State University, \\ 301 Saunders Hall, Blacksburg, VA 24061 \\ Additional index words. rhizotron, seasonal, temperature, budbreak, bare-root, transplant \\ establishment
}

\begin{abstract}
Description of early post-transplant root growth will help formulate best transplanting strategies for landscape trees. In this experiment, the dynamics of early root system regeneration of sugar maple (Acer saccharum Marsh. 'Green Mountain') and northern red oak (Quercus rubra $\mathrm{L}$.) were determined. Field-grown 4-year-old trees were transplanted bare-root into outdoor root observation containers (rhizotrons) in Oct. 1997, Nov. 1997, or Mar. 1998. All trees were grown in the rhizotrons until Oct. 1998 and then transplanted, with minimally disturbed rootballs, to field soil and grown for an additional two years. October-transplanted trees of both species began root regeneration earlier and regenerated more roots, as judged by accumulated root length on rhizotron windows, than Nov.- or March-transplanted trees. Median date for beginning root extension for sugar maples was 48, 22, and 0 days before budbreak for October-, November-, and Marchtransplanted trees, respectively. Median date for beginning root extension for northern red oak was 4, 21, and 14 days after budbreak for October-, November-, and Marchtransplanted trees, respectively. Height and trunk diameter growth were similar for all treatments within each species for 3 years after application of treatments. Early fall transplanting will result in earlier first season post-transplant root growth for sugar maple and northern red oak. Earlier post-transplant root growth will likely increase resistance to stress imposed by harsh landscape environments.
\end{abstract}

Poor post-transplant growth (transplant stress) of trees is primarily due to tissue water deficits induced by a restricted ability to absorb soil moisture (Carlson et al., 1988; Haase and Rose, 1993; Larson and Whitmore, 1970). The effects of soil water deficits after transplanting are diminished by a reduction in leaf area and an increased percentage of photosynthates allocated to the root system for transplanted compared to untransplanted trees (Struve and Joly, 1992), but predawn xylem water potentials of $-1.5 \mathrm{MPa}$ may inhibit root regeneration (Day and MacGillivray, 1975; Larson and Whitmore, 1970; Parvinder and Aussenac, 1989). Post-transplant tissue water deficits of $25 \%$ below full saturation can result in death (Larson, 1984). To best prevent or alleviate post-transplant water stress, rapid root growth into the surrounding backfill is necessary (Nambiar et al., 1979; Stone, 1955). Irrigation is essential since decreasing soil moisture in backfill-soil severely curtails root growth (Day and MacGillivray, 1975; Sivyer et al., 1996; Witherspoon and Lumis, 1986). Early, first-season root system regeneration is critical to transplant survival because it is here that desiccation stress must be resisted so that new roots can be grown to avoid plant moisture stress (Rietveld, 1989).

Received for publication 13 Aug. 2001. Accepted for publication $10 \mathrm{Jan} .2002$.

${ }^{1}$ Associate Professor; Dept. of Horticulture, Virginia Polytechnic Institute and State Univ., Blacksburg, VA 24061.

${ }^{2}$ Research Technician.

${ }^{3}$ Graduate Student
Rootball fibrosity affects transplant success (Harris et al., 1994). This is due in part to the increased likelihood of more intact root tips on fibrous rootballs. Intact lateral roots start elongation faster than severed roots, speeding root growth into backfill soil (Stone and Schubert, 1959). Arnold and Struve (1989) found that intact lateral roots of green ash (Fraxinus pennsylvanica Marsh.) seedlings begin extension in as little as $7 \mathrm{~d}$ after transplanting, whereas severed "long" roots require at least $17 \mathrm{~d}$ to regenerate new root tips. In addition, severed smaller diameter roots may regenerate root tips faster than larger diameter roots (Struve and Rhodus, 1988). Lee and Zieslin (1978) found that 1-2 mm diameter root sections of rose had the most potential for root regeneration and that the number of new roots decreased as root diameter increased. However, research by Lumis (1982) indicates that this may not be applicable to all species. First season post-transplant growth of sweetgum (Liquidambar styraciflua L.) (Kormanik, 1986) and northern red oak (Quercus rubra L.) (Ruehle and Kormanik, 1986) and size of loblolly pines (Pinus taeda L.) measured 7 years after transplanting (Kormanik et al., 1998) correlated positively with numbers of main lateral roots of seedling transplants.

Fall transplanting improved post-transplant growth and survival for some species (Harris and Bassuk, 1994; Harris et al., 1996), but not others (Kelly and Moser, 1983; Watson and Himelick, 1982). Interaction of plant physiological state at planting with the site environ- ment determine the severity and duration of transplanting stress (Rietveld, 1989). Genotype $\times$ environment interactions are likely responsible for some of the reported seasonal differences between species in response to transplanting. Low survival of fall-transplanted seedlings has been related to a low physiological potential for root regeneration at that time of year (Larson, 1984) and the inability of new transplants to grow roots in cold soils (Jenkinson, 1980). In contrast, late spring transplanting after a burst of root growth may result in reduced growth because of excessive carbohydrate drain (Dumbroff and Webb, 1978).

Developing effective transplanting strategies requires a more complete understanding of post-transplant root growth dynamics. Therefore, the purpose of the current research was to determine early root system regeneration characteristics for fall- and spring-transplanted sugar maples (easy-to-transplant) and northern red oaks (difficult-to-transplant). The early fall transplant date was chosen to coincide with the beginning of fall leaf drop. The later fall date coincided with final leaf drop, and the spring date represented conventional spring transplanting practices.

\section{Materials and Methods}

Bare-root, 2-m-tall sugar maple and 1.5$m$-tall northern red oak trees were obtained from J. Frank Schmidt and Sons, Inc. Nursery (Boring, Ore.) in late Winter 1995 and grown in field soil until application of treatments at the Urban Horticulture Center, near Blacksburg, Va. (U.S. Dept. of Agriculture zone 6a). Three transplant-timing treatments were randomly assigned as harvested and transplanted on 23 Oct. 1997, 18 Nov. 1997, or 17 Mar. 1998. At each harvest, rootballs were hand dug, washed free of soil, and trimmed to $40 \mathrm{~cm}$ diameter and depth. Beginning mean tree height (SE mean in parentheses) was 3.3 $(0.7) \mathrm{m}$ and $2.7(0.08) \mathrm{m}$, and trunk diameter, the mean of two measurements made in opposite directions $15 \mathrm{~cm}$ from ground level, was $4.4(0.11) \mathrm{cm}$ and $5.1(0.13) \mathrm{cm}$ for sugar maple and northern red oak, respectively. There were six trees per treatment per species (36 total trees including both species). Trees were transplanted in a completely randomized design (species separated) into 51-L containers (B-15; Lerio, Mobile, Ala.) in a pot-in-pot (PIP) production system (Ruter, 1997), also at the Urban Horticulture Center. The PIP system consisted of 51-L socket containers, $1.2 \mathrm{~m}$ within and $1.5 \mathrm{~m}$ between row spacings. The area between containers was covered with black landscape fabric, and an underground drainage system eliminated saturated substrates. Each production container was converted to a rhizotron by fitting with a $28-\mathrm{cm}$ wide $\times 28$-cm-long $\times 6$.4-mm-thick, clear polycarbonate sheet (GE Worldwide Manufacturing Sites, Mount Vernon, Ind.). A $25 \times 25-\mathrm{cm}$ square was marked with lines in 5-cm increments on each window. Rhizotron substrate was $100 \%$ milled pine bark $(\mathrm{pH}=5.1)$. Bark physical properties, determined as described by Niemiera et al. (1994), were air space $=24.3 \%$; 
bulk density $=200 \mathrm{~kg} \cdot \mathrm{m}^{-3}$; total porosity $=$ $79.8 \%$; container (water holding) capacity $=$ $55.5 \%$. When in rhizotrons, all trees were irrigated with a micro-irrigation system oncea-day as needed so as to maintain substrate moisture near container capacity. All trees were fertilized with $168 \mathrm{~g}$ of encapsulated slow-release fertilizer (18N-2.6P-9.9K; Osmocote, The Scotts Co., Maryville, Ohio) on 25 Mar. 1998. Substrate temperatures were monitored periodically with a thermocouple placed 20-cm deep and $1 \mathrm{~cm}$ from the observation window in a randomly selected rhizotron, and soil temperatures were monitored in one nursery row with a thermocouple also placed $20 \mathrm{~cm}$ deep.

Rhizotrons were checked at least twice weekly for root growth. Root length against the rhizotron windows was estimated periodically through 26 May 1998 with the line intersect method (Marsh, 1971; Newman, 1966). Spring budbreak was determined by estimating the percentage of buds on an individual tree that were open and had visible leaves. When $50 \%$ of the buds were open, the tree achieved spring budbreak. Final tree height and trunk diameters of both species were measured 15 Oct. 1998. All trees were then transplanted into single rows at the Urban Horticulture Center nursery on 19 Oct. and 15 Oct. for sugar maples and red oaks, respectively. All rootballs remained intact and were planted with minimal disturbance. After initial irrigation, trees were irrigated only during droughts. Trees were spaced $2 \mathrm{~m}$ apart, in a completely randomized design (species separated). Height and trunk diameter were measured on all trees in Nov. 1999 and Nov. 2000.

Data analysis. Root length against rhizotron windows was plotted over time for each treatment to reveal early-season root growth patterns. Change in root length over time on rhizotron windows was analyzed with repeated measures and single degree-of-freedom contrasts (Littell, 1989) within the GLM procedure of SAS (SAS version 8.1, Cary N.C.). Height and trunk diameter growth and total root length against rhizotron windows were analyzed with the GLM procedure of Minitab (Minitab version 12, State College, Pa.). Dates of first measurable root extension were noted for each tree and the median date was calculated for each treatment.

\section{Results and Discussion}

Sugar maple. All trees survived transplanting. Rhizotron substrate temperatures at the Oct. transplanting (Fig. 1) were near the point at which root growth is often limited (Harris et al., 1995), and temperatures dropped rapidly soon after. However, sugar maples grow roots sporadically throughout cold winter months (Harris and Fanelli, 1999; Morrow, 1950). Although October-transplanted trees broke bud 2 weeks before the other treatments (25 Apr. vs. 9 May), median date of first root growth (8 Mar.) was $48 \mathrm{~d}$ before budbreak, whereas median date for first measurable root extension for November- and March-transplanted trees (17 Apr. and 9 May) was 22 and $0 \mathrm{~d}$

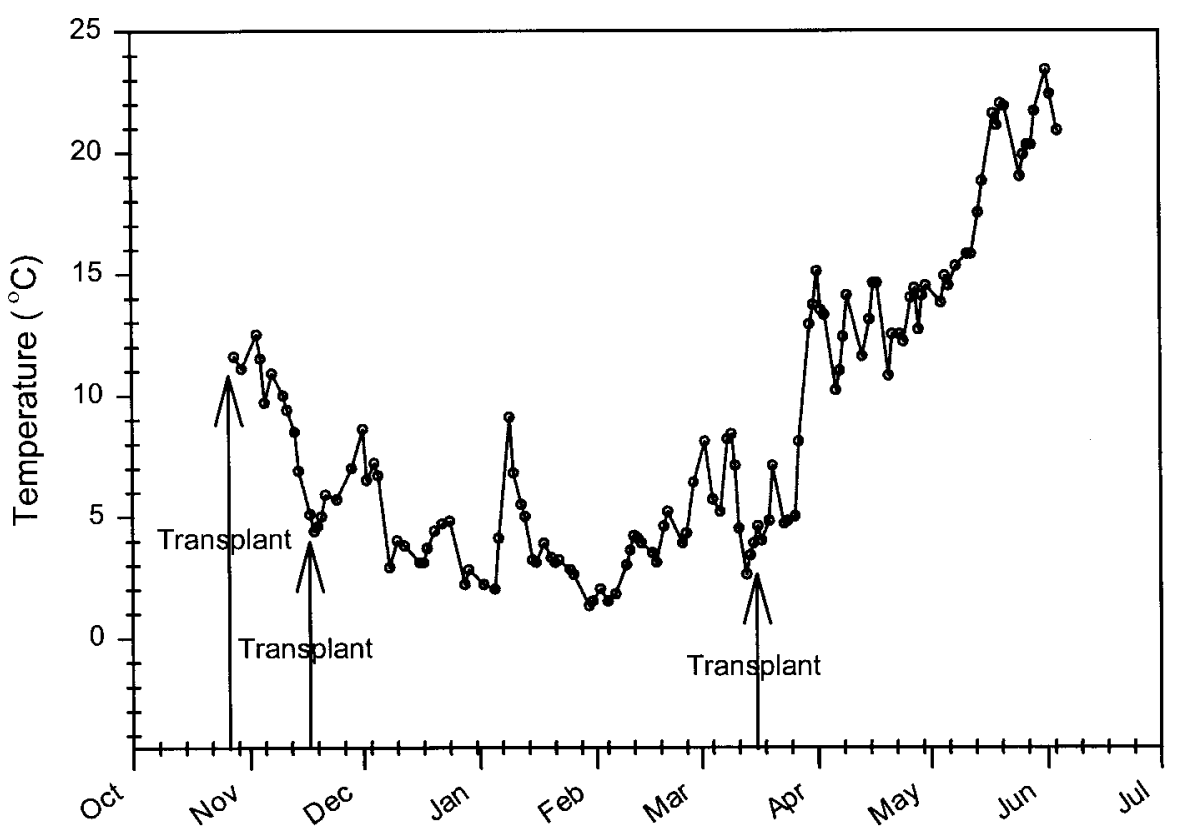

Fig. 1. Substrate temperature of rhizotrons. Each data point is a reading from one thermocouple, placed 20 $\mathrm{cm}$ deep and $1 \mathrm{~cm}$ from the observation window of a randomly selected rhizotron. Arrows indicate transplanting dates.

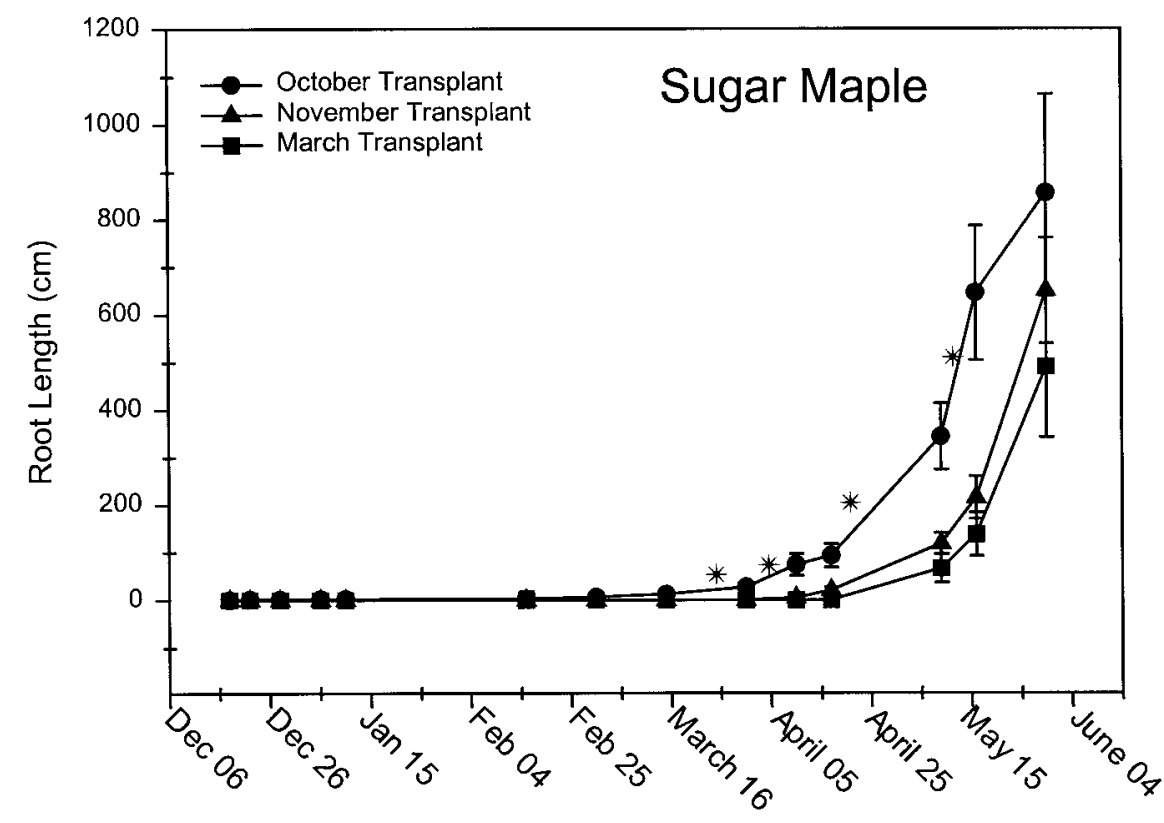

Fig. 2. Total root length against rhizotron windows over time for sugar maple (Acer saccharum Marsh. 'Green Mountain') trees transplanted on 23 Oct. 1997, 18 Nov. 1997, and 17 Mar. 1998. Data were analyzed as changes in root length (repeated measures) over time. Asterisks designate a time period where change in root length is significant according to repeated measures statistical analysis $(P \leq 0.05)$, and bars represent SE of the means. See Table 1 for statistics. $n=6$.

before budbreak, respectively. Reestablishment of the root system of October-transplanted trees was therefore well under way before shoot growth began. Faced with the uncertain environment of a landscape, early root growth before the onset of the high water demand resulting from a developing canopy likely will confer better drought resistance. In contrast to the considerable time of active root growth before budbreak present for either fall treatment, March-transplanted trees broke bud and began root extension simultaneously. Irrigation of the rootball for spring-transplanted trees is therefore especially critical.

Increase in root length against the rhizotron windows was more rapid for either fall transplant date than for the spring date, except for 10-16 Apr. and 16-30 May (Fig. 2; Table 1). More total root length was against the rhizotron windows for October transplants at each measurement date beginning on 1 Mar., except for the last measurement day, where there were no differences among treatments (data not shown). There was little evidence that treatment affected post-transplant height and trunk diameter increase (Table 2). 
Table 1. Single degree of freedom contrasts for change of root length against rhizotron windows during the specified time periods according to repeated measures analysis of variance for transplanted sugar maple (Acer saccharum Marsh. 'Green Mountain') and northern red oak (Quercus rubra L.). Trees were harvested and planted on 23 Oct. 1997, 18 Nov. 1997, or 17 Mar. 1998. $n=6$ for all treatments for both species except for oaks transplanted on 23 Oct. $(\mathrm{n}=4)$.

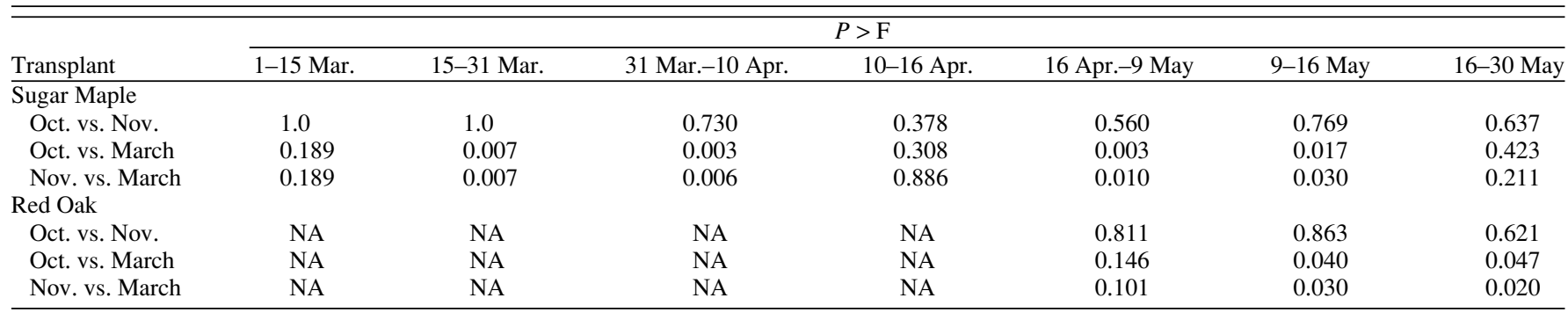

Northern red oak. All trees survived transplanting. Two trees were excluded from the study because they were upturned by heavy winds and were exposed to desiccating conditions. Transplanted northern red oak began root system regeneration later than sugar maple. Median dates for first root measurements of October-transplanted trees $=8$ Mar. for sugar maple and $=20$ May for northern red oak. Median dates for first root measurements of November-transplanted trees $=17$ Apr. for sugar maple and $=6$ June for northern red oak. Median dates for first root measurements for March-transplanted trees $=9$ May for sugar maple and 30 May for northern red oak. Johnson et al. (1984) found that 1-year-old (1-0) root pruned northern red oak required at least $50 \mathrm{~d}$ to regenerate roots. Struve and Rhodus (1988) found that pruned tap roots of 1-0 red oaks require at least $49 \mathrm{~d}$ to form new roots, although pruned small lateral roots required only $24 \mathrm{~d}$. In contrast, adventitious 1-0 green ash regenerates roots in as little as $17 \mathrm{~d}$ (Arnold and Struve, 1989). April-transplanted sugar maples first extended roots beyond balledand-burlapped rootballs $38 \mathrm{~d}$ after transplanting (Kelting et al., 1998). Relatively slow root regeneration is a significant factor in the transplant difficulties of northern red oak (Farmer, 1975).

Budbreak for all treatments was on 16 May. This was 4, 21, and $14 \mathrm{~d}$ before the median date for first root growth for October, November, and March transplants, respectively. Others have also reported that transplanted northern red oak begins root growth after budbreak (Johnson et al., 1984; Struve and Joly, 1992; Struve and Rhodus, 1988). Spring shoot growth before any new roots are produced further amplifies the transplant difficulties for northern red oak. As indicated in the current study, October-transplanted trees begin root growth shortly after budbreak and would likely be more resistant to subsequent environmental stresses than November or March transplants, which begin root growth 21 and $14 \mathrm{~d}$ after budbreak, respectively.

November and March transplants regenerated few roots, with November transplants having negligible root system regeneration (Fig. 3). October-transplanted trees began to grow roots more rapidly beginning 9 May (Fig. 3; Table 1), and they had more root length against rhizotron windows than Nov. or March transplants on 30 May (data not shown). Our data agree with Johnson et al. (1984), who found that shoot growth before the onset of

Table 2. Seasonal height and trunk diameter increase for sugar maple (Acer saccharum Marsh 'Green Mountain') and northern red oak (Quercus rubra L.). Trees were harvested and planted into rhizotrons on 23 Oct. 1997, 18 Nov. 1997, or 17 Mar. 1998 and transplanted from rhizotrons to field beds in October, 1998. $n=6$ for all treatments for both species except for oaks transplanted on 23 Oct. $(n=4)$.

\begin{tabular}{|c|c|c|c|c|c|c|}
\hline \multirow[b]{3}{*}{ Transplant } & 1998 & 1999 & 2000 & 1998 & 1999 & 2000 \\
\hline & \multicolumn{3}{|c|}{ Sugar maple } & \multicolumn{3}{|c|}{ Northern red oak } \\
\hline & \multicolumn{3}{|c|}{ Height increase $(\mathrm{m})$} & \multicolumn{3}{|c|}{ Height increase $(\mathrm{m})^{\mathrm{z}}$} \\
\hline October & $0.03(0.03)^{\mathrm{z}}$ & $0.27(0.06)$ & $0.69(0.10)$ & $0.11(0.06)$ & $0.15(0.07)$ & $0.16(0.09)$ \\
\hline November & $0.02(0.01)$ & $0.39(0.15)$ & $0.66(0.15)$ & $0.10(0.03)$ & $0.07(0.02)$ & $0.38(0.05)$ \\
\hline March & $0.06(0.03)$ & $0.18(0.05)$ & $0.60(0.15)$ & $0.08(0.02)$ & $0.11(0.05)$ & $0.26(0.05)$ \\
\hline \multirow[t]{2}{*}{$P>\mathrm{F}$} & 0.475 & 0.342 & 0.891 & 0.789 & 0.466 & 0.088 \\
\hline & \multicolumn{3}{|c|}{ Trunk diameter increase $(\mathrm{cm})$} & \multicolumn{3}{|c|}{ Trunk diameter increase $(\mathrm{cm})$} \\
\hline October & $0.69(0.08)$ & $1.12(0.11)$ & $1.51(0.07)$ & $0.66(0.14)$ & $0.63(0.13)$ & $1.57(0.1)$ \\
\hline November & $0.65(0.12)$ & $1.33(0.15)$ & $1.32(0.11)$ & $0.35(0.05)$ & $0.72(0.04)$ & $1.78(0.08)$ \\
\hline March & $0.68(0.11)$ & $0.98(0.05)$ & $1.29(0.07)$ & $0.50(0.12)$ & $0.78(0.07)$ & $1.57(0.08)$ \\
\hline$P>\mathrm{F}$ & 0.955 & 0.041 & 0.172 & 0.166 & 0.494 & 0.378 \\
\hline
\end{tabular}

${ }^{\mathrm{z}} \mathrm{SE}$ mean in parentheses.

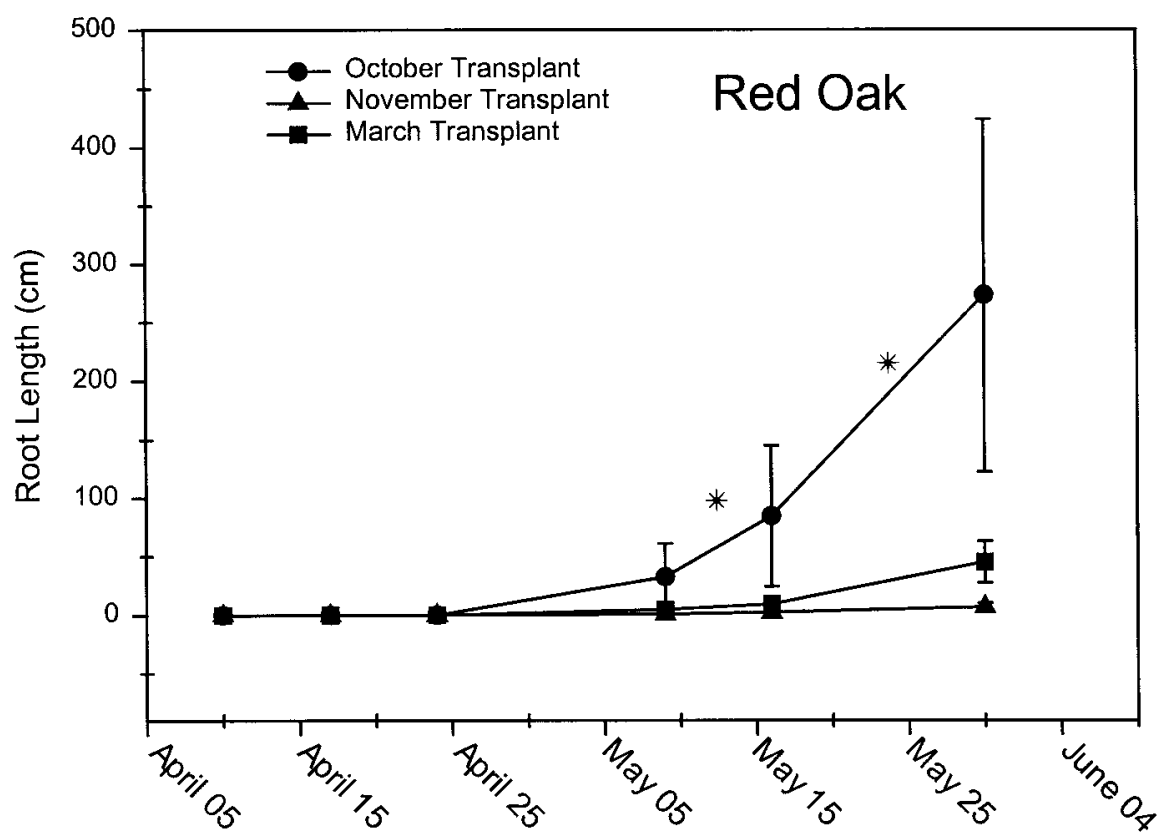

Fig. 3. Total root length against rhizotron windows over time for northern red oak (Quercus rubra L.) trees transplanted on 23 Oct. 1997, 18 Nov. 1997, and 17 Mar. 1998. Data were analyzed as changes in root length (repeated measures) over time. Asterisks designate a time period where change in root length is significant according to repeated measures statistical analysis $(P \leq 0.05)$, and bars represent SE of the means. See Table 1 for statistics. $n=6$ for November and March transplants. $n=4$ for October transplants.

root extension slowed root system expansion of northern red oak seedlings. There was little evidence that treatment affected post-transplant height and trunk diameter increase (Table 2). However, substrate moisture for both species was kept near container capacity during the rhizotron period. All trees were irrigated during dry periods after transplanting to the field, thus protecting them from the effects of periodic drought normally present in the landscape.

Conclusions. This research demonstrates that early-fall transplanted sugar maple and northern red oak begin root growth earlier and develop new root systems faster than springtransplanted trees. This is despite rhizotron 
substrate temperatures that were generally too low for root growth at transplanting (Fig. 1). Larson (1970) reported that 1-0 northern red oak regenerate roots poorly at $13{ }^{\circ} \mathrm{C}$ under greenhouse conditions, and Struve and Moser (1985) reported that soil temperatures below $16{ }^{\circ} \mathrm{C}$ significantly retarded root regeneration of scarlet oak (Quercus coccinea Muenchh.) seedlings. Substrate did not remain above 13 ${ }^{\circ} \mathrm{C}$ for any treatment in the current experiment until the end of April. Although soil in a nearby bed was consistently warmer than in the rhizotrons $\left(\right.$ mean $=2.0^{\circ} \mathrm{C}$ warmer; range $=$ $0.2-3.9^{\circ} \mathrm{C}$ ), soil temperatures were also unfavorable for root growth during the same period. The fact that sugar maple roots can grow in relatively cold soil (Harris and Fanelli, 1999; Morrow, 1950) no doubt contributed to earlier root growth for that species.

Transplanting stress is a combination of stress conditions and the process of adaptation and recovery (Rietveld, 1989). October-transplanted trees had more time than the other treatments for adaptation and recovery before the onset of very cold substrate (Fig. 1). Physiological processes of new root formation on October-transplanted trees may have been stimulated before cold limited further development.

In two similar studies, root growth of early fall-transplanted Turkish hazelnut (Corylus colurna L.) began root growth before trees transplanted in the spring (Harris et al., 2001), and early fall-transplanted fringe tree (Chionanthus virginicus L.) had more root growth after one growing season than late fallor spring-transplanted trees (Harris et al., 1996). In the current study, transplanting directly into a landscape subject to spring droughts would have likely favored the October transplants over the other treatments since root growth of October-transplanted trees began earlier and root systems regenerated faster. Early fall transplanting maximized the time between first root growth and spring budbreak for sugar maple and minimized the time after budbreak before root growth began for red oak. In light of our data and the other studies mentioned above, we conclude that for similar climates, transplanting in early fall confers earlier posttransplant root growth and therefore is the best time of year to transplant most cold-hardy deciduous landscape trees.

\section{Literature Cited}

Arnold, M.A. and D.K. Struve. 1989. Green ash establishment following transplant. J. Amer. Soc. Hort. Sci. 114:591-595.

Carlson, W.C., C.A. Harrington, P. Farnum, and S.W. Hallgren. 1988. Effects of root severing treatments on loblolly pine. Can. J. For. Res. 18:1376-1385.
Day, R.J. and G.R. MacGillivray. 1975. Root regeneration of fall-lifted white spruce nursery stock in relation to soil moisture content. For. Chron. 51:196-199.

Dumbroff, E.B. and D.P. Webb. 1978. Physiological characteristics of sugar maple and implications for successful planting. For. Chron. 54:9295.

Farmer, R.E.J. 1975. Dormancy and root regeneration of northern red oak. Can. J. For. Res. 5:176185.

Haase, D.L. and R. Rose. 1993. Soil moisture stress induces transplant shock in stored and unstored $2+0$ Douglas-fir seedlings of varying root volumes. For. Sci. 39:275-294.

Harris, J.R. and N.L. Bassuk. 1994. Seasonal effects on transplantability of scarlet oak, green ash, Turkish hazelnut and tree lilac. J. Arboric. 20:310-317.

Harris, J.R., N.L. Bassuk, and T.H. Whitlow. 1994. A window into below-ground growth of landscape trees: Implications for transplant success. HortTechnology 4:368-371.

Harris, J.R., N.L. Bassuk, R.W. Zobel, and T.H Whitlow. 1995. Root and shoot growth periodicity of green ash, scarlet oak, Turkish hazelnut, and tree lilac. J. Amer. Soc. Hort. Sci. 120:211216.

Harris, J.R. and J. Fanelli. 1999. Root and shoot growth periodicity of pot-in-pot red and sugar maple. J. Environ. Hort. 17:80-83.

Harris, J.R., P. Knight, and J. Fanelli. 1996. Fall transplanting improves establishment of balled and burlapped fringe tree (Chionanthus virginicus L.). HortScience 31:1143-1145.

Harris, J.R., R. Smith, and J. Fanelli. 2001. Transplant timing affects first-season root growth of Turkish hazelnut (Corylus colurna L.). HortScience 36:805-807.

Jenkinson, J.L. 1980. Improving plantation establishment by optimizing growth capacity and planting time of western yellow pines. Pac. SW For. Range Expt. Sta. Res. PSW-154:1-22.

Johnson, P.S., S.L. Novinger, and W.G. Mares. 1984. Root, shoot, and leaf area growth potentials of red oak planting stock. For. Sci. 30:10171026.

Kelly, R.J. and B.C. Moser. 1983. Root regeneration of Liriodendron tulipifera in response to auxin, stem pruning, and environmental conditions. J. Amer. Soc. Hort. Sci. 108:1085-1090.

Kelting, M., J.R. Harris, J. Fanelli, and B. Appleton. 1998. Humate-based biostimulants affect early post-transplant root growth and sapflow of balled and burlapped red maple. HortScience 33:342344.

Kormanik,P.P. 1986. Lateral root morphology as an expression of sweetgum seedling quality. For. Sci. 32:595-604.

Kormanik, P.P., S.S. Sung, and S.J. Zarnoch. 1998. Immature loblolly pine growth and biomass accumulation: correlations with seedlings firstorder lateral roots. S.J. Appl. For. 22:117-123.

Larson, M.M. 1970. Root regeneration and early root growth of red oak seedlings: influence of soil temperature. For. Sci 16:442-446.

Larson, M.M. 1984. Seasonal planting, root regeneration and water deficits of Austrian pine and arborvitae. J. Environ. Hort. 2:33-38.

Larson, M.M. and F.W. Whitmore. 1970. Moisture stress affects root regeneration and early growth of red oak seedlings. For. Sci. 16:495-498.

Lee, C.I. and N. Zieslin. 1978. Root regeneration of transplanted rootstocks with different scion cultivars of rose. HortScience 13:665-666.

Littell, R.C. 1989. Statistical analysis of experiments with repeated measures. HortScience 24:37-40.

Lumis, G.P. 1982. Stimulating root regeneration of landscape-size red oak with auxin root sprays. J. Arboric. 8:325-326.

Marsh, B. 1971. Measurement of length in random arrangement of lines (short communication). J. Appl. Ecol. 8:265-267.

Morrow, R.R. 1950. Periodicity and growth of sugar maple surface layer roots. J. For. 48:875-881.

Nambiar, E.K.S., G.D. Bowen and R. Sands. 1979. Root regeneration and plant water status of Pinus radiata $\mathrm{D}$. Don seedlings transplanted to different soil temperatures. J. Expt. Bot. 30:11191131.

Newman, E.I. 1966. A method of estimating the total length of root in a sample. J. Appl. Ecol. 3:139-145.

Niemiera, A.X., T.E. Bilderback, and C.E. Leda. 1994. Pine bark physical characteristics influence pour-through nitrogen concentrations. HortScience 29:789-791.

Parvinder, K. and G. Aussenac. 1989. Transplanting shock in Corsican pine and cedar of Atlas seedlings: internal water deficits, growth and root regeneration. For. Ecol. Mgt. 17:29-40.

Rietveld, W.J. 1989. Transplanting stress in bareroot conifer seedlings: Its development and progression to establishment. North. J. Appl. For. 6:99107.

Ruehle, J.L. and P.P. Kormanik. 1986. Lateral root morphology: a potential indicator of seedling quality in northern red oak. Res. Note SE US Dept. Agr. For. Serv. Southeast For. Expt. Sta. 344:6.

Ruter, J.M. 1997. The practicality of pot-in-pot. Amer. Nurs. Jan. 1:32-37.

Stone, E.C. 1955. Poor survival and physiological condition of planting stock. For. Sci. 1:90-94.

Stone, E.C. and G.H. Schubert. 1959. Root regeneration potential of ponderosa pine lifted at different times of the year. For. Sci. 5:322-332.

Struve, D.K. and R.J. Joly. 1992. Transplanted red oak seedlings mediate transplant shock by reducing leaf surface area and altering carbon allocation. Can. J. For. Res. 22:1441-1448.

Struve, D.K. and B.C. Moser. 1985. Soil temperature effects on root regeneration of scarlet oak seedlings. OARDC Res. Circ. 2841:12-14.

Struve, D.K. and T.W. Rhodus. 1988. Phenyl indole-3-thiobutyrate increases growth of transplanted 1-0 red oak. Can. J. For. Res. 18:131134.

Watson, G.W. and E.B. Himelick. 1982. Seasonal variation in root regeneration of transplanted trees. J. Arboric. 8:305-310.

Witherspoon, W. and G. Lumis. 1986. Root regeneration of Tilia cordata cultivars after transplanting in response to root exposure and soil moisture levels. J. Arboric. 12:165-168. 